\title{
Mucopolysaccharidosis type II: Identification of 30 novel mutations among Latin American patients
}

\author{
A.C. Brusius-Facchin ${ }^{\text {c,1 }}$, I.V.D. Schwartz ${ }^{\mathrm{a}, \mathrm{b}, \mathrm{c}, 1}$, C. Zimmer $^{\mathrm{c}}$, M.G. Ribeiro ${ }^{\mathrm{d}}$, A.X. Acosta ${ }^{\mathrm{e}}$, D. Horovitz ${ }^{\mathrm{f}}$, \\ I.L. Monlleó ${ }^{g}$, M.I.B. Fontes ${ }^{g}$, A. Fett-Conte ${ }^{\text {h}}$, R.P. Oliveira Sobrinho ${ }^{i}$, A.R. Duarte ${ }^{\mathrm{j}}$, R. Boy ${ }^{\mathrm{k}}$, P. Mabe ${ }^{1}$, \\ M. Ascurra ${ }^{\mathrm{m}}$, M. de Michelena ${ }^{\mathrm{n}}$, K.L. Tylee ${ }^{\circ}$, G.T.N. Besley ${ }^{\circ}$, M.C.V. Garreton ${ }^{\mathrm{p}}$, \\ R. Giugliani ${ }^{\text {a,b,c }}$, S. Leistner-Segal ${ }^{\text {a,b,c,* }}$
}

\footnotetext{
a Post Graduation Program in Medical Sciences, UFRGS, Porto Alegre, RS, Brazil

b Department of Genetics, UFRGS, Porto Alegre, Brazil

c Medical Genetics Service, Hospital de Clínicas de Porto Alegre, Brazil

${ }^{d}$ Clinical Genetics Service, IPPMG, UFRJ, Rio de Janeiro, Brazil

e Department of Pediatrics, UFBA, Salvador, Brazil

${ }^{\mathrm{f}}$ Instituto Fernandes Figueira, FIOCRUZ, Rio de Janeiro, Brazil

${ }^{g}$ Department of Pediatrics, UNCISAL, Maceió, Brazil

${ }^{\text {h }}$ Department of Molecular Biology, FAMERP, São José do Rio Preto, Brazil

${ }^{i}$ Department of Medical Genetics, UNICAMP, Campinas, Brazil

j Medical Genetics Service, IMIP, Recife, Brazil

${ }^{\mathrm{k}}$ Mother and Child Department, UERJ, Rio de Janeiro, Brazil

${ }^{1}$ Genetics and Metabolic Diseases Unit, INTA, University of Chile, Chile

m Department of Genetics, ILCS-UNA, Asunción, Paraguay

${ }^{n}$ Universidad Peruana Cayetano Heredia, Lima, Peru

o Willink Biochemical Genetics Unit, Royal Manchester Children's Hospital, Manchester, UK

${ }^{\mathrm{P}}$ Unidad de Genética Clínica, Hospital Roberto del Río, Santiago, Chile
}

\section{A R T I C L E I N F O}

\section{Article history:}

Received 22 August 2013

Accepted 23 August 2013

Available online 1 September 2013

\section{Keywords:}

Mucopolysaccharidosis type II

Glycosaminoglycans

Hunter syndrome

Iduronate-2-sulfatase

Genotype-phenotype correlation

\begin{abstract}
A B S T R A C T
In this study, 103 unrelated South-American patients with mucopolysaccharidosis type II (MPS II) were investigated aiming at the identification of iduronate-2-sulfatase (IDS) disease causing mutations and the possibility of some insights on the genotype-phenotype correlation The strategy used for genotyping involved the identification of the previously reported inversion/disruption of the IDS gene by PCR and screening for other mutations by $\mathrm{PCR} / \mathrm{SSCP}$. The exons with altered mobility on SSCP were sequenced, as well as all the exons of patients with no SSCP alteration. By using this strategy, we were able to find the pathogenic mutation in all patients. Alterations such as inversion/disruption and partial/total deletions of the IDS gene were found in 20/103 (19\%) patients. Small insertions/deletions/indels ( $<22$ bp) and point mutations were identified in 83/103 (88\%) patients, including 30 novel mutations; except for a higher frequency of small duplications in relation to small deletions, the frequencies of major and minor alterations found in our sample are in accordance with those described in the literature.
\end{abstract}

(C) 2013 Elsevier Inc. All rights reserved.

\section{Introduction}

Mucopolysaccharidosis type II (MPS II, McKusick 309900) is an $\mathrm{X}$-linked recessively inherited lysosomal storage disorder (LSD), resulting from deficiency of iduronate-2-sulfatase activity (IDS, EC 3.1.6.13). IDS is involved in the degradation of glycosaminoglycans

\footnotetext{
* Corresponding author at: Medical Genetics Service, Hospital de Clínicas de Porto Alegre, Rua Ramiro Barcelos, 2350, 90035-903 Porto Alegre, RS, Brazil. Fax: + 5551 33598010.

E-mail address: ssegal@hcpa.ufrgs.br (S. Leistner-Segal).

1 These authors contributed equally to the manuscript.
}

(GAGs) dermatan sulfate and heparan sulfate (DS-HS). Failure to hydrolyze the terminal iduronate-2-sulfate esters in these GAGs results in progressive accumulation of undegraded substrates within the lysosomes and in the clinical manifestations associated to MPS II [1].

The IDS gene is located on the Xq27/28 boundary of the long arm of the X-chromosome, comprising 9 exons spanning approximately $24 \mathrm{~kb}$ [2]. A pseudogene (IDS2), containing sequences homologous to exon II, intron 2, exon III and a chimerical intron 3-intron 7, is located approximately $20 \mathrm{~kb}$ far, telomeric to the active IDS gene, which makes this region prone to the occurrence of recombination events. Approximately $10-20 \%$ of MPS II patients present large 
gene alterations, including rearrangements and total IDS gene deletions, while $80-90 \%$ of them present small gene alterations $[3,4]$. According to the Human Gene Mutation Database [5], 479 different mutations in the IDS gene have been described until July 2013, most of which being private point mutations (52\%) or small deletions (17\%).

MPS II shows not only wide allelic heterogeneity, but also wide phenotypical heterogeneity. Patients are usually classified as having the severe, intermediate, or attenuated forms, depending mainly on the degree of mental retardation present $[1,4,6]$. In general, it seems that patients with the more severe forms are diagnosed earlier, have mental retardation that is evident by the age of 4-6 years, and are dead by the age of 10-15 years, while patients with the attenuated forms present normal intelligence and have a longer life expectancy [7,1,4]. However, as there is no standardized scoring index of severity for MPS II, this classification is not always reliable, especially in the case of patients diagnosed during childhood [4]. Consequently, studies of the genotypephenotype correlation are subject to various biases. As simple Mendelian disorders are in fact complex traits [8], it is likely that genotype-phenotype correlation does not exist for several IDS gene mutations [4].

In the present study, we have investigated 103 unrelated SouthAmerican MPS II patients in order to characterize their genotypes.

\section{Material and methods}

The Molecular Genetics Laboratory of the Medical Genetics Service of Hospital de Clínicas de Porto Alegre, Brazil, is a reference center for MPS diagnosis and receives samples from all over Brazil and from many Latin American countries. The indication for molecular analysis was based on clinical criteria, abnormal urinary GAG excretion and deficient IDS activity in dried blood, plasma, leucocytes or fibroblasts. In all cases, the possibility of multiple sulfatase deficiency was excluded by the measurement of the activity of another sulfatase. Regarding the origin of the 103 patients, 91/103 were from Brazil, 4/103 were from Chile, 2/103 were from Peru, 1/103 was from Paraguay, 2/103 were from Argentina, 1/103 was from Cuba and 2/103 were from Bolivia. DNA samples from 66 mothers and 22 affected brothers/cousins of the probands were also analyzed. This study was approved by the Institutional Review Board and by the National Research Ethics Committee of Brazil (project \#100066).

Genomic DNA of patients/relatives was extracted from blood following the salt precipitation method [9] and preserved in a Tris-EDTA $0.1 \mathrm{M}$ solution (Tris- $\mathrm{HCl}(10 \mathrm{mM}, \mathrm{pH} 7.5)$ and EDTA (1 mM, pH 8.0)). Samples were first analyzed through PCR/RFLP for the presence of the inversion/disruption of the IDS gene caused by intrachromosomal recombination between intron 7 of the gene and its homologous region on the pseudogene, according Lualdi et al. [10]. Samples with no evidence of the IDS-IDS2 recombination were analyzed by PCR/SSCP throughout the 9 exons and intron-exon boundaries of the IDS gene.

The PCR amplifications were performed using $5 \mu \mathrm{L}$ of buffer concentrated $10 \times(200 \mathrm{mM}$ Tris $\mathrm{HCl}(\mathrm{pH} 8.0) ; 500 \mathrm{mM} \mathrm{KCl}), 0.2 \mathrm{mM}$ dNTPs, 1.5-3.0 $\mathrm{mM} \mathrm{MgCl}_{2}, 0-6 \%$ of DMSO (Sigma), $1 \mathrm{U}$ of Taq DNA Polimerase (Invitrogen), and $20 \mathrm{pm}$ of each primer in a final reaction volume of $50 \mu \mathrm{L}$. PCR conditions were as follows: $94{ }^{\circ} \mathrm{C}$ for $5 \mathrm{~min}$; 34 cycles of $94{ }^{\circ} \mathrm{C}$ for $40 \mathrm{~s}, 50.5{ }^{\circ} \mathrm{C}-61{ }^{\circ} \mathrm{C}$ for $40 \mathrm{~s}$ (based on each exon) and $72{ }^{\circ} \mathrm{C}$ for $40 \mathrm{~s}$; and a final extension time of $72{ }^{\circ} \mathrm{C}$ for $10 \mathrm{~min}$. The primer sequences used for amplification of all the IDS exons and for the identification of the inversion/disruption events have been previously described [11-13]. Exon III was amplified using nested-PCR (amplification with primers $2 \mathrm{~A}$ and $3 \mathrm{~B}$ followed by amplification with primers $3 \mathrm{~A}$ and $3 \mathrm{~B}$ ) [12]. This extra step prevents the amplification of the pseudogene sequence.

Two negative PCRs for one determined exon of the IDS gene were considered as indicative of deletion of this exon. In the case of total deletions, DNA integrity was also tested by simultaneous amplification of the $\alpha$-1-antitrypsin gene.

SSCP was used to screen samples, using mutation detection enhancement gels (BMA) ranging from 0.7 to $1 \times$. The electrophoresis was carried out at $160 \mathrm{~V}$ for $16-24 \mathrm{~h}$ at room temperature.

The samples showing mobility shifts on SSCP were sequenced on ABI Prism $^{\mathrm{TM}} 3500$ Genetic Analyzer (Applied Biosystem). Mutations were confirmed on a second PCR product by the sequencing of both strands using the same methodology. In the case of novel missense mutations, 100 control alleles were analyzed in order to confirm the pathogenicity of the identified mutation, and bioinformatics analyses were performed using the Polyphen software. The samples of patients that did not show any alteration on SSCP were submitted to sequencing of the 9 IDS exons including exon/intron boundaries, according to the laboratory protocol.

After the identification of mutation in the DNA sample from the index case, family members were tested by restriction endonuclease analysis, PCR (mothers of patients presenting the inversion/disruption), SSCP or sequencing.

\section{Results}

\subsection{Detection of large gene alterations ( $n$ : 20/103) (Table 1)}

The recombination between the IDS gene and pseudogene (IDS2), which causes a disruption of the IDS gene and an inversion of the intervening region, was found in 13/103 (12\%) patients (patients $\mathrm{H} 1-\mathrm{H} 13$ ). Four patients (H14-H17) appear to have partial deletion of the IDS gene, after exon by exon amplification. Other three patients (H18-H20) showed a total deletion of the IDS gene and we performed wholegenome array-Comparative Genomic Hybridization (Array-CGH) to delineate the deletion breakpoints and to characterize the deletion extension; the deletion showed in the 3 patients extended from the proximal IDS region towards contiguous genes. The results were described previously by our group [14]. All of these patients have neurological impairment.

\subsection{Identification of small gene alterations ( $n: 83 / 103)$ (Tables 2 and 3)}

Amplification, SSCP analysis, and sequencing of exons I to IX of the IDS gene allowed for the identification of a small alteration $(<22 \mathrm{bp})$ in $83 / 103$ patients. The success rate found for SSCP screening was $72 \%$. All the missense point mutations were considered to be causative for the disease since the mutation was not found in 100 alleles of unaffected and unrelated controls and bioinformatic analyses, performed by Polyphen v.2, predicted that these mutations are probably damaging (score $>2$ ), it is with high confidence supposed to affect protein function/structure or possibly damaging (score 1,5-20) it is supposed to affect protein function or structure (Table 1). The multiple alignment in different species showed that mutations involve a highly conserved gene sequence (Table 2).

We have found 57 different small gene mutations in 83 patients. Data on the novel (n: 30) and recurrent mutations (n: 27) found in our sample are shown in Tables 1 and 2. Only 8 mutations were found in at least two unrelated patients: p.R88C, p.Y103X, p.W109X, p.S333L, c.1122C $>$ T, p.R443X, p.P467L and p.R468W. Intronic mutations were

Table 1

Characterization of large IDS gene alterations. Inversion and total/partial deletion (n: 20).

\begin{tabular}{lll}
\hline Patient & Large gene alteration & Reference \\
\hline H1-H13 & IDS/IDS2 inversion & Present work \\
H14 & Deletion of exons V, VI and VII & Present work \\
H15 & Deletion of exons IV, V, VI, VII and VIII & Present work \\
H16 & Deletion of exons V, VI and VII & Present work \\
H17 & Deletion of exons IV, V, VI, VII, VIII and IX & Present work \\
H18, H19, H20 & Total deletion of IDS gene & {$[14]$} \\
\hline
\end{tabular}


Table 2

Characterization of the novel IDS gene mutations described in this study. Insertions, duplications, and deletions (n: 7).

\begin{tabular}{|c|c|c|c|c|c|c|c|c|c|c|}
\hline Patient & Exon & \multicolumn{3}{|c|}{ Mutation (cDNA position) $)^{\mathrm{a}}$} & \multicolumn{2}{|c|}{$\begin{array}{l}\text { Conserved region among } \\
\text { IDS murine protein [15] }\end{array}$} & \multicolumn{2}{|c|}{ Protein alteration } & \multicolumn{2}{|c|}{ Comments } \\
\hline $\mathrm{H} 21$ & I & \multicolumn{3}{|c|}{ c.124_129dupATCATC } & \multicolumn{2}{|l|}{ Yes } & \multicolumn{2}{|c|}{ Insertion of two aa (ile) } & \\
\hline $\mathrm{H} 22$ & II & \multicolumn{3}{|c|}{ c.155delG } & \multicolumn{2}{|l|}{ Yes } & \multicolumn{2}{|c|}{ fs; 7 altered aa; truncated } & \multicolumn{2}{|c|}{ GG preceding the deleted $\mathrm{G}$} \\
\hline $\mathrm{H} 23$ & VI & \multicolumn{3}{|c|}{ c.805_808dupGACA } & \multicolumn{2}{|l|}{ Yes } & \multicolumn{2}{|c|}{ fs; 25 altered aa } & \multirow{3}{*}{\multicolumn{2}{|c|}{ The sequence inserted is similar to a close sequence }} \\
\hline $\mathrm{H} 24$ & Intron & \multirow{2}{*}{\multicolumn{3}{|c|}{$\begin{array}{l}\text { IVS7-16_IVS7-9 } \\
\text { del gcttttta ins GGTGGGCTCTAGG }\end{array}$}} & \multirow{2}{*}{\multicolumn{2}{|c|}{ Yes }} & \multirow{2}{*}{\multicolumn{2}{|c|}{ Splice site mutation }} & & \\
\hline & VII & & & & & & & & & \\
\hline $\mathrm{H} 25$ & VIII & \multicolumn{3}{|c|}{ c.1134_1152dupCCCTTACCTCGACCCTTTT } & \multicolumn{2}{|l|}{ Yes } & \multicolumn{2}{|c|}{ fs; 5 altered aa; truncated } & \multirow{2}{*}{\multicolumn{2}{|c|}{$\begin{array}{l}1 \text { patient already described having a deletion } \\
\text { in the same region: GAGAAGGCA [16] }\end{array}$}} \\
\hline $\mathrm{H} 26$ & IX & \multicolumn{3}{|c|}{ c.1300_1306dupGAAGGCA } & \multicolumn{2}{|c|}{ Not highly } & fs; 12 alt & ed aa; truncated & & \\
\hline $\mathrm{H} 27$ & IX & c.1349_1364de & TCCGTACC & CCTGG & No & & fs; 5 alter & aa; truncated & & \\
\hline Point mu & ations (n: & & & & & & & & & \\
\hline Patient & Exon & Mutation & $\begin{array}{l}\text { cDNA } \\
\text { position }^{a}\end{array}$ & $\begin{array}{l}\text { Sequence } \\
\text { change }\end{array}$ & & $\begin{array}{l}\text { Conserved codon } \\
\text { human and murin }\end{array}$ & $\begin{array}{l}\text { mong } \\
\text { IDS [15] }\end{array}$ & $\begin{array}{l}\text { PSIC profile scor } \\
\text { amino acid vari }\end{array}$ & $\begin{array}{l}\text { for two } \\
\text { ts }[17]^{\mathrm{b}}\end{array}$ & Comments \\
\hline $\mathrm{H} 28$ & II & p.D45V & 134 & GAT to GTT & & Yes & & 2.980 & & $\mathrm{D} 45 \mathrm{~N}[18]$ \\
\hline $\mathrm{H} 29$ & II & p.D45G & 134 & GAT to GGT & & Yes (catalytic site) & & 2.530 & & $\mathrm{D} 45 \mathrm{~N}[18]$ \\
\hline $\mathrm{H} 30$ & II & p.S61Y & 180 & TCC to TAC & & Yes & & 2.245 & & No mutation described in this codon yet \\
\hline H31 & II & p.Q80R & 239 & CAG to CGG & & Yes (near catalytic & site) & 2.306 & & Splice site mutation; Q80X $[18,19]$ \\
\hline $\mathrm{H} 32$ & II & p.Q81Y & 240 & CAA to TAA & & Yes & & 2.475 & & No mutation described in this codon yet \\
\hline $\mathrm{H} 33$ & III & p.C84Y & 250 & TGC to TAC & & Yes & & 3.681 & & C84X [18] \\
\hline H34 & III & p.W109X & 325 & TGG to TGA & & Yes & & - & & W109K [20] \\
\hline $\mathrm{H} 35$ & III & p.W109X & 325 & TGG to TGA & & Yes & & - & & Same as above \\
\hline H36 & III & p. R95S & 409 & AGG to AGC & & Yes (catalytic site) & & 2.355 & & R95T, R95G [12,21] \\
\hline H37 & III & p.H138Y & 411 & CAC to TAC & & Yes (catalytic site) & & 2.667 & & H138D [16] \\
\hline H38 & III & c. $417 \mathrm{G}>\mathrm{C}$ & 417 & CCTGgt to CCT & TCgt & Yes (catalytic site) & & - & & Splice site mutation \\
\hline H39 & IV & p.P160H & 479 & CCT to CAT & & Yes & & 2.775 & & P160R [22] \\
\hline $\mathrm{H} 40$ & IntronV & c. $709-2^{\mathrm{A}}>\mathrm{T}$ & $709-2$ & $\begin{array}{l}\text { ccaagGAA to } \\
\text { ccatggaa }\end{array}$ & & Yes & & - & & Splice site mutation; 709-2A>G [23] \\
\hline H41 & VI & p.Q239X & 715 & CAG to TAG & & Yes & & - & & No mutation described in this codon yet \\
\hline $\mathrm{H} 42$ & VI & p.N265K & 793 & AAc to AAG & & Yes & & 1.817 & & N265I [3] \\
\hline $\mathrm{H} 43$ & VII & p.L314H & 941 & CTC to CAC & & Yes & & 2.446 & & L314P [24] \\
\hline $\mathrm{H} 44$ & VII & p.D308H & 922 & GAT to CAT & & Yes & & 2.530 & & D308N, D308E [24,25] \\
\hline H45 & VII & p.D334Y & 1000 & GAT to TAT & & Yes & & 2.980 & & D334N, D334G [16,26] \\
\hline $\mathrm{H} 46$ & VII & p.D334V & 1000 & GAT to GTT & & Yes & & 2.980 & & D334G,D334N [16,26] \\
\hline $\mathrm{H} 47$ & VIII & c. $1007 \mathrm{G}>\mathrm{T}$ & 1007 & tagGG to tagTC & & Yes & & - & & $\begin{array}{l}\text { Splice site mutation; } 1007 \mathrm{G}>\mathrm{A} \text {, } \\
1006 \mathrm{G}>\mathrm{A}[16,23,26]\end{array}$ \\
\hline $\mathrm{H} 48$ & VIII & p.H342P & 1025 & CAT to CTT & & Yes & & 3.552 & & H342Y, H342Q [27,28] \\
\hline $\mathrm{H} 49$ & VIII & p.E344K & 1031 & GAA to $\mathrm{AAA}$ & & Yes & & 1.833 & & No mutation described in this codon yet \\
\hline $\mathrm{H} 50$ & IX & p.V503D & 1508 & GTT to GAT & & Yes & & 2.038 & & Same as above \\
\hline H51 & IX & p.Y536X & 1608 & TAT to TAA & & Yes & & - & & Same as above \\
\hline
\end{tabular}

aa: amino acid; fs: frameshift.

a cDNA numbering follows [29], beginning with the A of the initiation codon. Gene sequence follows GenBank entry M58342.

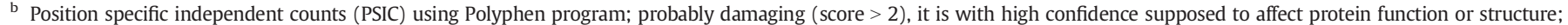
possibly damaging (score $1,5-20$ ), it is supposed to affect protein function or structure.

found in 3/100 (3\%) patients, all of which involving the consensus splice donor or acceptor site.

Regarding the type of the 57 different small alterations found, 2/57 (3.5\%) were deletions, $2 / 57$ (3.5\%) were indels, 4/57 (7.0\%) were duplications, and 49/57 (85\%) were point mutations. Among point mutations, $7 / 49$ (10.6\%) were splice site, 10/49 (21.2\%) were nonsense, and $32 / 49$ (68\%) were missense mutations.

In 23/103 (22\%) patients, the mutation was located in exon IX. Considering only the patients that presented exonic point mutations (n: 75/83), exon IX was the exon with the highest frequency of mutations found (21/75 patients), followed by exons III, VIII and VII $(17 / 75,13 / 75,12 / 75$ patients each) and exons II, 8/75 patients (Tables 2 and 3). Point mutations seemed to be rare in exons $\mathrm{V}$ ( 1 patient each), I and IV (2 patients each).

\subsection{Family studies}

The analysis performed in 63 available mothers of MPS II patients showed that $48 / 63$ (76\%) were carriers. Seven of 10 mothers of patients presenting the inversion/disruption were carriers. Also, all brothers/ cousins with MPS II that were studied (n: 22) presented the same mutation identified in the proband.

\section{Discussion}

This is the largest sample of Latin American MPS II patients reported to date. Our findings regarding the genotype analysis are, in general, in agreement with the literature. We have found great allelic heterogeneity among our patients ( 57 different mutations in 103 patients), and 30 novel mutations. Only 8 point mutations were recurrent in two or more unrelated patients (p.R88C, p.Y103X p.W109X, p.S333L, c.1122 C>T, p.R443X, p.P467L and p.R468W); of these, only p.P467L did not involve CpG sites.

Discordant with the literature is the relatively higher number of small duplications/insertions in relation to the small deletions that we found $(7.0 \%$ versus $3.5 \%)$. According to the literature, the frequency for small duplications/insertions ranges from $1.5 \%$ to $6 \%$ and from 10 to $20 \%$ for small deletions $[24,30,31]$.

As expected, the exon with the highest frequency of point mutations was exon IX (n: 21 patients). It has been reported that, while the distribution of small rearrangements in the IDS gene seems random, point mutations tend to be more frequent in exons III, VIII, VII and IX [32]. In our sample, the number of patients showing point mutations in exons $\mathrm{I}$, IV, and $\mathrm{V}$ was almost the same. We found a high frequency of the mutation c. $1122 \mathrm{C}>\mathrm{T}$, in codon 374 . This is a silent mutation that creates an 
Table 3

Recurrent IDS gene point mutations found in this work and worldwide patients described in the literature.

\begin{tabular}{|c|c|c|c|}
\hline Patients ${ }^{\mathrm{a}}$ & Mutation $^{\mathrm{b}}$ & Origin & Clinical phenotype (literature) ${ }^{\mathrm{c}}$ \\
\hline H52 a, b, c & R8X & Brazil & $\begin{array}{l}\text { Intermediate: } 1 \text { patient }[3] ; \\
\text { attenuated: } 2 \text { patients }[18,30]\end{array}$ \\
\hline H53 & Y54X & Brazil & Severe: 1 patient [33] \\
\hline $\mathrm{H} 54$ & A77D & Brazil & Attenuatted [34] \\
\hline H55 & N63D & Brazil & Mild: 1 patient [12] \\
\hline H56 & A85T & Brazil & $\begin{array}{l}\text { Severe: } 1 \text { patient }[26] \text {; intermediate: } \\
2 \text { patients }[16,24,25,32,35,36]\end{array}$ \\
\hline H57 & P86L & Brazil & [37] \\
\hline H58 & S87N & Brazil & Attenuated: 1 patient [37] \\
\hline H59,60,61 & $\mathrm{R} 88 \mathrm{C}$ & Brazil & Severe: 3 patients [32] \\
\hline $\mathrm{H} 62$ & $\mathrm{R} 88 \mathrm{H}$ & Brazil & Severe: 3 patients $[32,33]$ \\
\hline $\mathrm{H} 63,64$ & Y103X & Brazil & Intermediate [38] \\
\hline $\mathrm{H} 65$ & T130I & Brazil & Mild: 1 patient [33] \\
\hline H66 & P231L & Brazil & $\begin{array}{l}\text { Mild: } 1 \text { patient [25]; severe: } \\
1 \text { patient [31] }\end{array}$ \\
\hline $\mathrm{H} 67$ & c.708G > A & Brazil & $\begin{array}{l}\text { Severe: } 1 \text { patient [28]; } \\
\text { intermediate: } 1 \text { patient [32] }\end{array}$ \\
\hline H68 & c.709-2A > G & Paraguay & [23] (no clinical description) \\
\hline H69 & S305P & Brazil & Attenuated: 1 patient [39] \\
\hline $\mathrm{H} 70, \mathrm{H} 71, \mathrm{H} 72, \mathrm{H} 73$ & S333L & Brazil & $\begin{array}{l}\text { Severe: } 5 \text { patients } \\
{[16,18,26,31,33,40,41]}\end{array}$ \\
\hline H74 & S333L & Chile & Same as above \\
\hline $\mathrm{H} 75$ & $\mathrm{H} 335 \mathrm{R}$ & Brazil & Intermediate: 2 patients $[16,31]$ \\
\hline H76 & G336V & Brazil & Severe [42] \\
\hline $\begin{array}{l}\mathrm{H} 77, \mathrm{H} 78, \mathrm{H} 79, \mathrm{H} 80, \\
\mathrm{H} 81, \mathrm{H} 82, \mathrm{H} 83\end{array}$ & c. $1122 \mathrm{C}>\mathrm{T}$ & Brazil & $\begin{array}{l}\text { Intermediate: } 1 \text { patient [3]; } \\
\text { attenuated: } 21 \text { patients } \\
{[11,12,18,21,31,32,37,43,44]}\end{array}$ \\
\hline H84 & c. $1122 \mathrm{C}>\mathrm{T}$ & Bolivia & Same as above \\
\hline H85 a, b & Q389X & Brazil & Severe: 2 patients $[19,46]$ \\
\hline H86 & $\mathrm{C} 422 \mathrm{Y}$ & Chile & Intermediate: 1 patient [25] \\
\hline $\begin{array}{l}\mathrm{H} 87, \mathrm{H} 88, \mathrm{H} 89 \\
\text { H90,H91 }\end{array}$ & $\mathrm{R} 443 \mathrm{X}$ & Brazil & $\begin{array}{l}\text { Severe: } 4 \text { patients }[11,16,21,36] \text {; } \\
\text { intermediate: } 5 \text { patients } \\
\text { [16,32,38,40]; attenuated: } \\
6 \text { patients }[3,25,30,31]\end{array}$ \\
\hline H92 & $\mathrm{R} 443 \mathrm{X}$ & Bolivia & Same as above \\
\hline $\mathrm{H} 93$ & P467L & Chile & Severe: 2 patients $[16,21]$ \\
\hline H94 a, b, H95 & P467L & Brazil & Same as above \\
\hline H96,H97,H98,H99 & R468W & Brazil & $\begin{array}{l}\text { Severe: } 10 \text { patients } \\
{[12,24,31,21,15,37,44,45] ;} \\
\text { attenuated: } 2 \text { patients }[45,47]\end{array}$ \\
\hline H100 & R468W & Argentina & Same as above \\
\hline H101 & R468Q & Argentina & $\begin{array}{l}\text { Severe: } 30 \text { patients } \\
{[3,12,16,18,24,26,32,38,40,48,49] \text {; }} \\
\text { intermediate: } 1 \text { patient }[12]\end{array}$ \\
\hline H102 & D478G & Brazil & {$[45]$} \\
\hline H103 a, b, c & L482X & Brazil & Intermediate: 2 patients $[26,30]$ \\
\hline
\end{tabular}

MDD: delay in motor development; LDD: delay in language development; MR: mental retardation; BP: behavioral problems; NR: neurological regression; NA: not available; see specific reference for the clarification of the criteria used for the classification of clinical severity in each study.

a Patients described with the same number and different letters (a, b, c,) are relatives.

b cDNA numbering follows [29], beginning with the A of the initiation codon.

c Cases when author has not characterized the clinical phenotype or when the clinical phenotype was unknown have not been included in this column.

alternative splice site with loss of 20 IDS amino acids and that corresponds to around $45 \%$ of the mutations in exon VIII [32]. This was expected, given the ethnic background of our samples and the fact that this is the most frequent mutation of the IDS gene found in Spain and Portugal, where more than 25 patients have been reported. All of these patients have an attenuated phenotype, suggesting that the very low percentage of normal transcript was sufficient to avoid a severe phenotype $[21,25,30,40]$. On its turn, the high frequency of point mutations in exon IX may be explained by the existence of mutational hotspots (codon 468, for example) and by the size of this exon (473 bp, approximately twice the size of the remaining exons).

Regarding the pathogenicity of the novel missense mutations described, it is important to point out that all occur in codons that are conserved among the human and the murine IDS [15] and that they were not found in 100 control alleles. Of the 63 mothers tested for mutation analysis, 19 are obligatory carriers, based on family pedigree. Taking into account only the mothers that are not mandatory carriers $44 / 63$, we identified $46 \%$ of carriers and $24 \%$ as non-carriers, which is in accordance with the rate of spontaneous mutation proposed by Haldane. Assuming no selection among carriers and non-carriers, and the fact that MPS II is X-linked recessive, it is expected that approximately $1 / 3$ of the cases are secondary to new mutations [50]. In the work of Chase et al. [51], 23\% of mothers of patients with MPS II were identified as non-carriers, similar to the expected value (approximately 33\%); however, Machill et al. [52], Rathmann et al. [32], Froissart et al. [16] and Bellows and Thompson [53] found a ratio of carrier mothers (approximately 90\%) higher than expected (66\% approximately).

Although there are no uniform criteria to classify the clinical severity of patients with MPS II, most studies that analyze the correlation between genotype and phenotype in this disease classify patients into the severe (presence of severe or moderate mental retardation), intermediate (absence or presence of mild mental retardation and presence of severe somatic disease) or the attenuated form (absence of mental retardation and presence of attenuated somatic disease). However, these studies usually do not provide a more detailed clinical description of the patients.

For instance, IDS gene total deletions and the p.S333L mutation are always reported as being associated with the severe phenotype $[4,24,30,31,32]$, while the $\mathrm{c} .1122 \mathrm{C}>\mathrm{T}$ mutation (codon 374) is always reported as being associated with normal intelligence [30]; two of our patients present a severe phenotype. Patients with, p.A85T, p.R443X, p.R468W and p.R468Q mutations, are reported as having the severe or the attenuated form of MPS II. Therefore, some few mutations present correlation with the severe form (total deletions, p.S333L), other few mutations present correlation with the attenuated form (c.1122C $>$ T), while a greater number of mutations are correlated both with the severe form and the attenuated form (p.A85T, p.R443X, p.R468W, p.R468Q). It is important to point out that these generalizations can only be made in relation to the small number of recurrent mutations, since most mutations in the IDS gene are private or have been described in a limited number of patients.

The three patients that present a frameshift mutation, clearly appear to have a severe phenotype.

According to our findings, point mutations (including mutations in splice sites) seem to be associated with any of the clinical phenotypes. It is interesting to point out that, different from what was expected, the clinical phenotypes associated with the 7 nonsense mutations found range from the attenuated to the severe form of the disease. The mutations p.Y54X and p.Y536X are clearly associated with the severe and the attenuated phenotype, respectively. Mutation p.Y536X is the nearest to the carboxyl terminus of the IDS protein described to date. It may be compared with the recurrent mutation p.Q531X, which has already been described in two patients with the attenuated form of MPS II [16,40]; both mutations lead to the synthesis of a protein missing the C-terminal amino acIDS removed during IDS protein maturation and should not prevent the IDS processing to the lysosome [4]. The phenotypes found in the patients that present the following recurrent mutations (p.R8X, p.Q389X, p.R443X, and p.L482X), are in agreement with those reported in the literature: The p.R8X phenotype could be explained by the proximity of the mutation to the initiation codon, a context in which nonsense-mediated decay could be circumvented [10], and by the presence of the low-fidelity stop codon, which may result in limited natural read through possibilities [30]. In patients carrying the mutation p.R443X a complete spectrum of phenotypes from attenuated to severe has been described suggesting that the natural read-through could vary between individuals and/or that other factors could influence the phenotype [30]. It seems that the severity of nonsense mutations, in the case of the IDS gene, shows a relation with its location within the gene, since mutations located in the amino and carboxy terminal ends tend to be associated with attenuated phenotypes. Interestingly, one of the novel point mutations described in 
the carboxy terminal end (p.V503D) is also associated with the attenuated phenotype.

As to the mutations that are being described in this study for the second time in the literature (p.S87N, c.709-2A>G, p.C422Y), there is total discordance as to the phenotype associated to p.S87N: the Brazilian patient clearly presents the severe form of MPS II, while the other patient described [37] presents the attenuated form. In our sample, the phenotype associated with c.709-2A $>\mathrm{G}$ is the severe one; however, Lissens et al. [23] did not describe the phenotype of their patient. There is some agreement as to the phenotype associated with p.C422Y: the patient being described herein presents an extremely attenuated form of MPS II, while Gort et al. [25] classified their patient as having the intermediate form. Moreover, we are describing two brothers with the c.708G $>$ A, who apparently have no neurological involvement. Interestingly, this mutation was described in one patient with the intermediate form [32] as well as in other patient with the severe form of MPS II [18]. The clinical phenotypes associated with the other recurrent mutations found (p.A85T, p.S333L, c.1122C $>$ T, p.P467L, p.R468W and p.R468Q) are in agreement with those of the literature.

We believe that the methodology employed in this study is appropriate for both the diagnosis and the identification of mutations in patients with MPS II and possible carriers. The correlation between genotype and phenotype for MPS II exists for a small subset of mutations, being probably influenced by other factors that modulate the residual activity of the IDS. Therefore, in the present state of knowledge, the identification of the mutation present in individuals with MPS II has, as main objective, the genetic counseling of families.

\section{Acknowledgments}

This study was supported by grants from Roscoe Brady program of NORD (National Organization of Rare Disorders), CAPES/Brazil and Institutional FIPE-HCPA funds. ACBF receives a governmental postdoctoral scholarship from CNPq. SLS, IVDS and RG are recipients of CNPq research grants.

\section{References}

[1] E.F. Neufeld, J. Muenzer, The mucopolysaccharidoses, in: C.R. Scriver, A.L. Beaudet, W.S. Sly, D. Valle (Eds.), The Metabolic and Molecular Basis of Inherited Disease 7th ed., McGraw-Hill, New York, 2001, pp. 1191-1211.

[2] J. Wilson, C.P. Morris, D.S. Anson, T. Occhiodoro, J. Bielick, P.R. Clements, J.J. Hopwood, Hunter syndrome: isolation of an iduronate-2-sulfatase cDNA clone and analysis of patient DNA. Proc. Natl. Acad. Sci. U. S. A. 87 (1990) 8531-8535.

[3] M. Filocamo, G. Bonucelli, F. Corsolini, R. Mazzotti, R. Cusano, R. Gatti, Molecular analysis of 40 Italian patients with mucopolysaccharidosis type II: new mutations in the iduronate-2-sulfatase (IDS) gene, Hum. Mutat. (2001) 164-165.

[4] R. Froissart, I. Moreira da Silva, N. Guffon, D. Bozon, I. Maire, Mucopolysaccharidosis type II genotype/phenotype aspects, Acta Paediatr. Suppl. 439 (2002) 82-87.

[5] HGMD - The Human Gene Mutation Database, www.uwcm.ac.uk/uwcm/mg/ search2012.

[6] I.V. Schwartz, M.G. Ribeiro, J.G. Mota, M.B. Toralles, P. Correia, D. Horovitz, E.S Santos, I.L. Monlleo, A.C. Fett-Conte, R.P. Sobrinho, D.Y. Norato, A.C. Paula, C.A. Kim, A.R. Duarte, R. Boy, E. Valadares, M. De Michelena, P. Mabe, C.D. Martinhago, J.M. Pina-Neto, F. Kok, S. Leistner-Segal, M.G. Burin, R. Giugliani, A clinical study of 77 patients with mucopolysaccharidosis type II, Acta Paediatr. Suppl. 96 (2007) 63-70.

[7] I.D.S. Young, P.S. Harper, R.G. Newcombe, I.M. Archer, A clinical and genetic study of Hunter syndrome 2 Differences between the mild and severe forms, J. Med. Genet. 19 (1982) 408-411.

[8] K.M. Dipple, E.R.B. McCabe, Phenotypes of patients with "simple" Mendelian disorders are complex traits: thresholds, modifiers, and systems dynamics, Am. J. Hum. Genet. 66 (2000) 1729-1735.

[9] A.S. Miller, D.D. Dykes, H.F. Polesky, A simple salting-out procedure for extracting DNA from human nucleated cells, Nucleic Acid Res. 16 (1988) 1215.

[10] S. Lualdi, S. Regis, M. Di Rocco, F. Corsolini, M. Stroppiano, D. Antuzzi, M. Filocamo, Characterization of Idorunate-2-sulfatase gene-pseudogene recombinants in eight patients with mucopolysaccharidosis type II revealed by rapid PCR-based method Hum. Mutat. 25 (2005) 491-497.

[11] S. Bunge, C. Steglich, C. Zuther, M. Beck, C. Phillip-Morris, E. Schwinger, A. Schinzel, J.J. Hopwood, A. Gal, Iduronate-2-sulfatase gene mutations in 16 patients with mucopolysaccharidosis type II (Hunter syndrome), Hum. Mol. Genet. 2 (1993) 1871-1875.
[12] S.L. Goldenfum, E. Young, H. Michelakakis, S. Tsagarakis, B. Winchester, Mutation analysis in 20 patients with Hunter disease, Hum. Mutat. 7 (1996) 76-78.

[13] K. Lagerstedt, S. Karsten, B.M. Carlsberg, W.J. Kleijer, T. Tönnesen, U. Petterson, M.L. Bondenson, Double-strand breaks may initiate the inversion mutation causing the Hunter syndrome, Hum. Mol. Genet. 6 (4) (1997) 627-633.

[14] A.C. Brusius-Facchin, C.F. De Souza, I.V. Schwartz, M. Riegel, M.I. Melaragno, P. Correia, L.M. Moraes, J. Llerena, R. Giugliani, S. Leistner-Segal, Severe phenotype in MPS II patients associated with a large deletion including contiguous genes, Am. J. Med. Genet. A 158A (2012) 1055-1059.

[15] A. Daniele, C.J. Faust, G.E. Herman, P. Di Natale, A. Ballabio, Cloning and characterization of the cDNA for the murine iduronate sulfatase gene, Genomics 16 (1993) 755-757.

[16] R. Froissart, I. Maire, G. Millat, S. Cudry, A.M. Birot, V. Bonnet, O. Bouton, D. Bozon, Identification of iduronate sulfatase gene alterations in 70 unrelated Hunter patients, Clin. Genet. 53 (1998) 362-368.

[17] V. Ramensky, P. Bork, S. Sunyaev, Human non-synonymous SNPs: server and survey, Nucleic Acids Res. 17 (2002) 3894-3900.

[18] E. Vafiadaki, A. Cooper, L.E. Heptinstall, C.E. Hatton, M. Thornley, J.E. Wraith, Mutation analysis in 57 unrelated patients with MPS II (Hunter disease), Arch. Dis. Child. 79 (1998) 237-241.

[19] R. Carrozo, R. Tonlorenzi, F. Corsolini, R. Gatti, Two new nonsense mutations (Q80X and Q389X) in patients with severe Hunter syndrome, Hum. Mutat. 7 (1996) 184-185.

[20] S. Emre, M. Terzioğlu, T. Coskun, A. Tokath, I. Ozalp, V. Müller, J. Hopwood, Biochemical and molecular analysis of mucopolysaccharidoses in Turkey, Turk. J. Pediatr. 44 (2002) 13-17.

[21] I.M. da Silva, R. Froissart, H.M. dos Santos, C. Caseiro, I. Maire, D. Bonzon, Molecular basis of mucopolysaccharidosis type II in Portugal: identification of four novel mutations, Clin. Genet. 60 (2001) 316-318.

[22] R.H. Flomen, P.M. Green, D.R. Bentley, F. Giannelli, E. Green, Detection of point mutations and a gross deletion in six Hunter syndrome patients, Genomics 13 (1992) 543-550.

[23] W. Lissens, S. Seneca, I. Liebaers, Molecular analysis in 23 Hunter disease families, J. Inherit. Metab. Dis. 20 (1997) 453-456.

[24] K. Isogai, K. Sukegawa, S. Tomatsu, T. Fukao, X.Q. Song, Y. Yamada, S. Fukuda, T. Orii, $\mathrm{T}$. Kondo, Mutation analysis in the iduronate-2-sulphatase gene in 43 Japanese patients with mucopolysaccharidosis type II (Hunter disease), J. Inherit. Metab. Dis. 21 (1998) 60-70.

[25] L. Gort, A. Chabás, M.J. Coll, Hunter disease in the Spanish population: molecular analysis in 31 families, J. Inherit. Metab. Dis. 21 (1998) 655-661.

[26] P. Li, A.B. Bellows, J.N. Thompson, Molecular basis of iduronate-2-sulphatase gene mutations in patients with mucopolysaccharidosis type II (Hunter syndrome), J. Med. Genet. 36 (1999) 21-27.

[27] H.D.H.D. Vallance, L.L. Bernard, M.M. Rashed, D.D. Chiu, G.G. Le, J.J. Toone, D.A.D.A. Applegarth, M.M. Coulter-Mackie, Identification of 6 new mutations in the iduronate sulfatase gene, Hum. Mutat. 13 (1999) 338.

[28] K. Timms, F. Edwards, J.W. Belmont, J.R.W. Yates, R.A. Gibbs, Reassessment of biochemically determined Hunter syndrome carrier status by DNA testing, J. Med. Genet. 35 (8) (1998) 646-649.

[29] J.T. den Dunnen, S.E. Antonorakis, Nomenclature for the description of sequence variations, Hum. Genet. 109 (2001) 121-124.

[30] R. Froissart, I.M. Da Silva, I. Maire, Mucopolysaccharidosis type II: an update on mutation spectrum, Acta Paediatr. Suppl. 96 (2007) 71-77.

[31] Y.B. Sohn, C.S. Ki, C.H. Kim, A.R. Ko, Y.J. Yook, S.J. Lee, S.J. Kim, S.W. Park, S. Yeau, K. Kwon, S.J. Han, E.W. Choi, S.Y. Lee, J.W. Kim, D.K. Jin, Identification of 11 novel mutations in 49 Korean patients with mucopolysaccharidosis type II, Clin. Genet. 2 (2012) 185-190

[32] M. Rathmann, S. Bunge, M. Beck, H. Kresse, A. Tylki-Szymanksa, A. Gal, Mucopolysaccharidosis type II (Hunter syndrome): mutation "hot spots" in the iduronate-2-sulfatase gene, Am. J. Hum. Genet. 59 (1996) 1202-1209.

[33] H. Zhang, J. Li, X. Zhang, Y. Wang, W. Qiu, J. Ye, L. Han, X. Gao, X. Gu, Analysis of the IDS gene in 38 patients with Hunter syndrome: the c.879G > A (p.Gln293Gln) synonymous variation in a female create exonic splicing, PLoS One 8 (2011) 22951.

[34] C.R. Quaio, H. Grinberg, M.L. Vieira, A.C. Paula, G.N. Leal, I. Gomy I, S. Leistner-Segal, R. Giugliani, D.R. Bertola, C.A. Kim, Report of a Large Brazilian Family With a Very Attenuated Form of Hunter Syndrome (MPS II), JIMD Rep. 4 (2012) 125-128.

[35] S. Tomatsu, K. Sukegawa, G.G. Trandafirescu, M.A. Gutierrez, T. Nishioka, S. Yamaguchi, T. Orii, R. Froissart, I. Maire, A. Chabas, A. Cooper, P. Di Natale, A. Gal, A. Noguchi, W.S. Sly, Differences in methylation patterns in the methylation boundary region of IDS gene in Hunter syndrome patients: implications for CpG hot spot mutations, Eur. J. Hum. Genet. 14 (2006) 838-845.

[36] S. Keeratichamroen, J.R. Cairns, D. Wattanasirichaigoon, P. Wasant, L. Ngiwsara, P. Suwannarat, S. Pangkanon, J. Kuptanon, P. Tanpaiboon, T. Rujirawat, S. Liammongkolkul, J. Svasti, Molecular analysis of the iduronate-2-sulfatase gene in Thai patients with Hunter syndrome, J. Inherit. Metab. Dis. 2 (2008) 303-311.

[37] E. Popowska, M. Rathmann, A. Tylki-Szymanska, S. Bunge, C. Steglich, E. Schwinger, A. Gal, Mutations of the iduronate-2-sulfatase gene in 12 Polish patients with mucopolysaccharidosis type II, Hum. Mutat. 5 (1995) 97-100.

[38] S. Karsten, W. Voskoboeva, B.M. Carlberg, W.J. Kleijer, T. Tönnesen, U. Pettersson, M.L. Bondenson, Identification of 9 novel IDS gene mutations in 19 unrelated Hunter syndrome (mucopolysaccharidosis type II) patients, Hum. Mutat. 12 (1998) 433.

[39] J.H. Chang, G.J. Lee-Chen, S.P. Lin, C.K. Chuang, Characterization of a novel p.S305P and a known c.1006 + 5G > C splice site mutation in human iduronate-2-sulfatase associated with mucopolysaccharidosis type II, Clin. Chim. Acta 384 (2007) 167-170.

[40] K. Sukegawa, S. Tomatsu, T. Fukao, H. Iwata, X.Q. Song, Y. Yamada, S. Fukuda, K. Isogai, T. Orii, Mucopolysaccharidosis type II (Hunter disease): identification and characterization of eight point mutations in the iduronate-2-sulfatase gene in Japanese patients, Hum. Mutat. 5 (1995) 136-143. 
[41] S. Karsten, E. Voskoboeva, S. Tishkanina, U. Petterson, X. Krasnopolskaja, M.L. Bondenson, Mutational spectrum of the iduronate-2-sulfatase (IDS) gene in 36 unrelated Russian MPS II patients, Hum. Genet. 103 (6) (1998) $732-735$.

[42] T. Kato, Z. Kato, I. Kuratsubo, N. Tanaka, T. Ishigami, J. Kajihara, K. Sukegawa-Hayasaka, K. Orii, K. Isogai, T. Fukao, N. Shimozawa, T. Orii, N. Kondo, Y. Suzuki, Mutational and structural analysis of Japanese patients with mucopolysaccharidosis type II, J. Hum. Genet. 50 (2005) 395-402.

[43] E.B. Simon-Schiff, G. Bach, J.J. Hopwood, D. Abeliovich, Mutation analysis of Jewish Hunter patients in Israel, Hum. Mutat. 4 (1994) 263-270.

[44] C.C. Hartog, A.A. Fryer, M.M. Upadhyaya, Mutation analysis of iduronate-2-sulphatase gene in 24 patients with Hunter syndrome: characterization of 6 novel mutations, Hum. Mutat. 14 (1999) 87.

[45] W. Schröder, K. Wulff, M. Wehnert, G. Seidlitz, F.H. Herrmann, Mutations of the Iduronate-2-sulfatase (IDS) gene in patients with Hunter syndrome (mucopolysaccharidosis II), Hum. Mutat. 4 (1994) 128-131.

[46] J. Jonsson, E.L. Aronovich, S.E. Braun, C.B. Whitley, Molecular diagnosis of mucopolysaccharidosis type II (Hunter syndrome) by automated sequencing and computer-assisted interpretation: toward mutation mapping of the iduronate-2-sulfatase gene, Am. J. Hum. Genet. 56 (1995) 597-607.

[47] P.L. Crotty, S.E. Braun, R.A. Anderson, C.B. Whitley, Mutational R468W of the iduronate-2-sulphatase gene in mild Hunter syndrome (mucopolysaccharidosis type II) confirmed by in vitro mutagenesis and expression, Hum. Mol. Genet. 1 (1992) 755-758.

[48] C.B. Whitley, R.A. Anderson, E. Aronovich, P.L. Crotty, K. Anyane-Yeboa, D. Russo, D. Warburton, Caveat to genotype-phenotype correlation in mucopolysaccharidosis type II: discordant clinical severity of R468W and R468Q mutations of the iduronate-2-sulfatase gene, Hum. Mutat. 2 (1993) 235-237.

[49] G.R.D. Villani, N. Balzano, M. Grosso, F. Salvatore, P. Izzo, P. Di Natale, Mucopolysaccharidosis type II: identification of six novel mutations in Italian patients, Hum. Mutat. 10 (1997) 71-75.

[50] J.B.S. Haldane, The rate of spontaneous mutation of a human gene, J. Genet. 31 (1935) 317-326.

[51] D.S. Chase, A.H. Morris, A. Ballabio, S. Pepper, F. Giannelli, M. Adinolfi, Genetics of Hunter syndrome: carrier detection, new mutations, segregation and linkage analysis, Ann. Hum. Genet. 50 (Pt 4) (1986 Oct) 349-360.

[52] G. Machill, G. Barbujani, G.A. Danieli, F.H. Herrmann, Segregation and sporadic cases in families with Hunter's syndrome, J. Med. Genet. 28 (6) (Jun. 1991) 398-401(PubMed PMID: 1908009).

[53] A.B. Bellows, J.N. Thompson, Mutational analysis, heterozygote detection, and haplotype analysis in 48 families affected with Hunter syndrome, 6th International Symposium on Mucopolysaccharidosis and Related Diseases and International Symposium on Innovative Therapies, May 19-21, University of Minnesota, Minneapolis, USA, 2000, p. 4. 